\title{
Molecular sexing in the formation of pairs of blue-and-yellow macaw (Ara ararauna) in reintroduction programs
}

\author{
Sexagem molecular na formação de pares de arara-canindé (Ara ararauna) em programas de \\ reintrodução \\ Sexado molecular en la formación de parejas de guacamayo azul y amarillo (Ara ararauna) en
} programas de reintroducción

\begin{abstract}
Blue and yellow macaw is a species which does not show sexual dimorphism and is threatened by animal traffic. The identification of heterosexual pairs is important for reintroduction programs. The aim of this work was select parameters for sexing and use them to determine the frequency of heterosexual pairs in a population of blue-and-yellow macaws allocated in a Wild Animal Screening Center. Blood samples from 23 macaws were collected and genomic DNA extracted by Tris/SDS washes. Allele-specific molecular markers for sexing were amplified by PCR, and identified on $2 \%$ agarose gel. Three pairs of primers were tested: Pair 1 (P2/P8), Pair 2 (1237L/1272H) and Pair $3(2550 \mathrm{~F} / 2718 \mathrm{R})$. For the determination of animal pairs, all individuals had their social behavioral acts observed. The results showed that the low complexity DNA extraction protocol used was adequate. Pairs 2 and 3 of primers were effective for sexing and the Pair 3 was the most efficient. The study also showed that in the sample studied, the composition of males and females was similar ( 0.4 males $n=10$ and 0.6 females $n=13) ; 70 \%(n=16)$ of the individuals formed pairs and $75 \%$ $(n=12)$ of the pairs were heterosexual and the others male-male or female-female pairs. These results were used in the management of the animals in the reintroduction program.
\end{abstract}

Keywords: Reintroduction programs; Illegal trade; Molecular markers; Psittacidae; Heterosexual and homosexual pairs.

\section{Resumo}

Arara-canindé, ave que não apresenta dimorfismo sexual, é uma espécie ameaçada pelo tráfico de animais. A identificação de pares heterossexuais é importante para programas de reintrodução. O objetivo deste trabalho foi selecionar parâmetros de sexagem e utilizá-los para determinar a frequência de pares heterossexuais em uma população de araras-canindé alocada em um Centro de Triagem de Animais Silvestres. Amostras de sangue de 23 araras foram coletadas e o DNA genômico extraído por lavagens com Tris/SDS. Marcadores moleculares alelo-específicos para sexagem foram amplificados por PCR e identificados em gel de agarose a $2 \%$. Três pares de primers foram testados: 
Par 1 (P2/P8), Par 2 (1237L/1272H) e Par 3 (2550F/2718R). Para a determinação dos pares, todos os indivíduos tiveram seus comportamentos sociais observados. Os resultados mostraram que o protocolo de extração de DNA de baixa complexidade utilizado foi adequado. Os pares 2 e 3 de primers foram eficazes para a sexagem e o Par 3 foi o mais eficiente. $\mathrm{O}$ estudo também mostrou que, na amostra estudada, a composição de machos e fêmeas foi semelhante $(0,4$ machos $n=10$ e 0,6 fêmeas $n=13) ; 70 \%(n=16)$ dos indivíduos formavam pares e $75 \%(n=12)$ dos pares eram heterossexuais e os demais pares macho-macho ou fêmea-fêmea. Esses resultados foram utilizados no manejo dos animais no programa de reintrodução.

Palavras-chave: Programas de reintrodução; Comércio ilegal; Marcadores moleculares; Psittacidae; Pares heterossexuais e homossexuais.

\section{Resumen}

Guacamayo azul y amarillo, ave que no presenta dimorfismo sexual, es una especie amenazada por el tráfico de animales. La identificación de parejas heterosexuales es importante para los programas de reintroducción. El objetivo de este trabajo fue seleccionar parámetros para sexar y utilizarlos para determinar la frecuencia de parejas heterosexuales en una población de guacamayos azules y amarillos asignados en un Centro de Detección de Animales Salvajes. Se recolectaron muestras de sangre de 23 guacamayo azul y amarillo y se extrajo el ADN genómico mediante lavados con Tris/SDS. Los marcadores moleculares alelo-específicos para sexar se amplificaron mediante PCR y se identificaron en gel de agarosa al 2\%. Se probaron tres pares de cebadores: Par 1 (P2/P8), Par 2 (1237L/1272H) y Par 3 (2550F/2718R). Para la determinación de las parejas de animales, se observaron los comportamientos sociales de todos los individuos. Los resultados mostraron que el protocolo de extracción de ADN de baja complejidad utilizado fue adecuado. Los pares 2 y 3 de cebadores fueron efectivos para sexar y el par 3 fue el más eficiente. El estudio también mostró que en la muestra estudiada, la composición de hombres y mujeres fue similar $(0.4$ hombres $n=10$ y 0.6 mujeres $n=13) ; 70 \%$ $(\mathrm{n}=16)$ de los individuos formaban parejas, y $75 \%(\mathrm{n}=12)$ de las parejas eran heterosexuales y el resto de parejas hombrehombre o mujer-mujer. Estos resultados se utilizaron en el manejo de los animales en el programa de reintroducción.

Palabras clave: Programas de reintroducción; Tráfico ilegal; Marcadores moleculares; Psittacidae; Parejas heterosexuales y homosexuales.

\section{Introduction}

Brazil is considered a megadiverse country (IBGE, 2001; Sick, 1997). Among Brazilian biodiversity, birds stand out for representing $17.82 \%$ of all bird species described in the world (Gill, Donsker \& Rasmussen, 2020; Piacentini et al., 2015). However, despite the brazilian biodiversity of birds, according to the Red List of Threatened Species (2015), Brazil is considered the country with the largest number of wild bird species threatened with extinction (apud Piacentini et al., 2015). Several species of birds, because they have exuberant colors and vocalization ability, contribute to this group of animals being considered the most sought after for illegal trade (Sick, 1997).

Among the groups of birds illegally traded, the order Psittaciformes can be cited (Souza \& Soares-Filho, 2005). Psittaciformes, currently, is composed of three families: (i) Cacatuidae, family of cockatoos; and (ii) Psittacidae (which is divided into the subfamilies Loriinae and Psittacinae) and (iii) Strigopidae, composed of endemic species from New Zealand (Joseph, Toon, Schirtzinger, Wright \& Schodde, 2012). With representatives of small size (such as parakeets) to large wings (such as macaws), psittacines belong to the family Psittacidae. Psittacidae also has a marked presence in Brazil, with 87 species (Piacentini et al., 2015).

The blue-and-yellow macaw are among the largest birds of the Psittacidae family, varying between 71 and 90 centimeters in length (Rodríguez-Mahecha, Suárez, Arzuza \& Hernández, 2005) and are found mainly in the north of South American and also in the south of Central America (BirdLife International, 2018). A common behavior in species of the Psittacidae family, which includes the blue-and-yellow macaws, is social monogamy, in the reproductive season pairs are formed that remain throughout life (Sick, 1997).

In 1999, Bagemihl, analyzed sexual behavior in 450 species of birds and mammals, concluding that there are variations of the standard behavior established between males and females. Among the birds, these variations were observed in several species, from courtship to the formation of pairs composed of animals of the same sex. The establishment of homosexual pairs in birds has also been documented in monogamous species (Jankowiak, Tryjanowski, Hetmański \& Skórka, 2018). 
In birds, the apparent sexual dimorphism established by morphological characteristics is often due to feather coloration and body size (Sick, 1997). Many bird species do not exhibit marked sexual dimorphism (Sick, 1997). Among them are parrots (Allgayer \& Cziulik, 2007), which include the blue-and-yellow macaw (Ara ararauna). Considering that this species does not present sexual dimorphism, the use of technical resources for sexing becomes indispensable in the process of pair identification. In order to guarantee the reproductive success of the species in captivity or the management in the release of birds in reintroduction projects, the identification of the pairs formed by the animals should be considered.

Molecular markers, associated with the identification of the alleles present on the sex chromosomes $\mathrm{Z}$ and $\mathrm{W}$, can be amplified by PCR using different primer pairs (Ágh, Kovács, Nemesházi \& Szabó, 2018; Franco-Gutiérrez, Álvarez-Cardona \& Soto-Calderón, 2017; Ong \& Vellayan, 2008; Sulandari \& Zein, 2012). The objective of the present study was to select parameters of molecular sexing of blue-and-yellow macaw and the use of these to determine the frequency of heterosexual pairs in the population of wild blue-and-yellow macaw allocated in one Wildlife Screening Center (CETAS) of Brazil.

\section{Methodology}

The animals in the present study were 23 adult blue-and-yellow macaw (A. ararauna), allocated in CETAS-VDC, located in the Parque Municipal da Serra do Periperi (14.8337 $\mathrm{S}, 40.8373^{\circ} \mathrm{W}$ ), Vitoria da Conquista city (Bahia) - Brazil. The authors assert that all procedures contributing to this work comply with the ethical standards of the relevant national and institutional guides on the care and use of animals in research. This research project was approved by the CEUA (Ethics Committee on the Use of Animals) of the Multidisciplinary Institute of the Federal University of Bahia (IMS / UFBA), protocol number 050/2017. This project was registered in SISGEN (National System for Management of Genetic Heritage and Associated Traditional Knowledge), registration number ACF8348. This is a descriptive quantitative research (Dalfovo, Lana \& Silveira, 2008; Pereira, Shitsuka, Parreira \& Shitsuka, 2018). All animals studied were identified with aluminum washers (these are cited as CETASUFBA in the Results item). Blood samples were collected from all the individuals studied, being obtained through a small cut on the nails of the macaws, using specialized pliers. The blood was collected on strips of $110 \mathrm{~mm}$ filter paper (JProlab®), previously cut out under sterile conditions, and allowed to dry for usage in DNA extraction, following the procedures described by Smith and Burgoyne (2004).

DNA extraction was performed using the protocol also described by Smith and Burgoyne (2004) with modifications. We did not used $5 \mathrm{M}$ guanidine thiocyanate or $95 \%$ ethanol in the washes, we increased the time in the water bath from 10 minutes to 20 minutes and we used $4 \mu \mathrm{L}$ of eluant, instead of $1 \mu \mathrm{L}$.

The filter paper strips with dry biological material (blood) were washed using $100 \mathrm{mM}$ Tris- $0.1 \%$ SDS solution, with gentle and uninterrupted shaking for about 30 minutes. Then the strips with the biological material were again washed three times with Milli-Q water (ultrapure) under the same stirring conditions mentioned for the first wash. Finally, after discarding the water used in the washes, $50 \mu \mathrm{l}$ of ultrapure water was added to the microtubes (with the strips), and these were kept in a water bath for 20 minutes. The strips were then discarded and the eluant $(4 \mu \mathrm{L})$ (containing the extracted DNA) stored. Qualitative and quantitative analyzes of DNA were performed using NanoDrop 2000® (Thermo Scientific, 44 MA, USA). 1uL of each sample is used for analysis.

The molecular markers were amplified from the genomic DNA extracted by PCR using Taq DNA Polymerase (Invitrogen ${ }^{\circledR}, \mathrm{SP}$, Brazil) in a thermal cycler (Applied Biosystems ${ }^{\circledR}$ ). To determine the most appropriate pair of primers to identify the sex of blue-and-yellow macaw, three pairs of allele-specific primers were tested. following (with modifications) previously established protocols. Previously established protocols were followed (with modifications). The modifications occurred, for the three primer pairs, both in relation to PCR reactions and to the thermocycling program. 
For P2/P8 allele-specific primers (P2 5'-TCTGCATCGCTAAATCCTTT-3' and P8 5'CTCCCAAGGATGAGRAAYTG-3') (Griffiths, Double, Orr \& Dawson, 1998), here called Pair of primers 1, the Griffiths et al. (1998) protocol was modified. The conditions of the PCR reactions used were: $1 x$ Buffer; $3.0 \mathrm{mM} \mathrm{MgCl} 2 ; 0.5 \mu \mathrm{M}_{2}$ of each primer; $0.2 \mathrm{mM}$ dNTP; $0.17 \mathrm{U} / \mu \mathrm{L}$ Taq DNA polymerase and $4 \mu \mathrm{L}$ extracted DNA (final reaction volume $=16 \mathrm{uL}$ ). The cycling program used was denaturation at $94{ }^{\circ} \mathrm{C}$ for 4 minutes; followed by 40 cycles of denaturation at $94{ }^{\circ} \mathrm{C}$ for 30 seconds, annealing at $51{ }^{\circ} \mathrm{C}$ for 45 seconds and extension $72{ }^{\circ} \mathrm{C}$ for 45 seconds; with final extension at $72{ }^{\circ} \mathrm{C}$ of 5 minutes.

For 1237L/1272H allele-specific primers (1237L 5'-GAGAAACTGTGCAAAACAG-3' and 1272H 5'TCCAGAATATCTTCTGCTCC-3') (Kahn, St. John \& Quinn, 1998), here called Pair of primers 2, the (Jensen, Pernasetti \& Durrant, 2003) parameters were modified. The conditions of the PCR reactions used were: $1 \mathrm{X} \mathrm{Buffer;} 4 \mathrm{mM} \mathrm{MgCl} 2 ; 0.2 \mathrm{mM}$ dNTP; $2 \mu \mathrm{M}$ of each primer (1237L / 1272H); $0.02 \mathrm{U} / \mathrm{uL}$ of Taq DNA Polymerase and $4 \mu \mathrm{L}$ of the extracted DNA (final reaction volume of $18 \mathrm{uL}$ ). The cycling program used was initial denaturation at $95^{\circ} \mathrm{C}$ for 5 minutes; followed by 35 cycles of denaturation at $95{ }^{\circ} \mathrm{C}$ for 45 seconds, annealing at $59{ }^{\circ} \mathrm{C}$ for 45 seconds and extension at $72{ }^{\circ} \mathrm{C}$ for 1 minute; final extension at $72^{\circ} \mathrm{C}$ for 4 minutes.

For 2250F/2718R allele-specific primers (2550F 5'-GTTACTGATTCGTCTACGAGA-3' and 2718R 5'ATTGAAATGATCCAGTGCTTG-3') (Fridolfsson \& Ellegren, 1999), here called Pair of primers 3, the Vucicevic et al. (2012) protocol was modified. The PCR reaction conditions used were: $1 \mathrm{X}$ Buffer; $1.5 \mathrm{mM} \mathrm{MgCl}_{2} ; 0.1 \mathrm{mM} \mathrm{dNTP} ; 1.0 \mu \mathrm{M}$ of each primer (2250F / 2718R); $0.05 \mathrm{U} / \mu \mathrm{L}$ of Taq DNA Polymerase and $4 \mu \mathrm{L}$ of extracted DNA (final $20 \mu \mathrm{L}$ PCR reaction volume). The cycling program used was initial denaturation at $95^{\circ} \mathrm{C}$ for 4 minutes; followed by 35 cycles of denaturation at $95{ }^{\circ} \mathrm{C}$ for 30 seconds, annealing at $53{ }^{\circ} \mathrm{C}$ for 30 seconds and extension at $72{ }^{\circ} \mathrm{C}$ for 45 seconds; final extension at $72^{\circ} \mathrm{C}$ for 4 minutes.

PCR amplified allele-specific DNA fragments were electrophoresed on $2 \%$ agarose gel, and stained with ethidium bromide (EtBr). The DNA bands were visualized using UV light.

Observational ad libitum methodology (Altmann, 1974) was used to identify the formation of pairs. The identification was through continuous observation (four months, four days a week, four hours a day, totaling 256 hours) of the behavior of the macaws in the enclosures where they were being kept. The enclosure was $12 \mathrm{~m}$ long x $6 \mathrm{~m}$ wide x $5.50 \mathrm{~m}$ high, all sides delimited by a screen, three perches and a tree. The individuals had free access to water and food (pieces of banana, papaya, apple, orange, cucumber and sunflower seeds). The identification of the pairs (heterosexual and homosexual) occurred through the observation of four social behavioral acts (Table 1) for at least three continuous weeks per pair, previously described in the literature (Favoretto, 2016). These results were used in the management of the animals in the release of bird in reintroduction program.

Table 1. Social behavioral acts used to identify the heterosexual and homosexual pairs of blue-and-yellow macaw.

\begin{tabular}{ll}
\hline Behavioral acts & Details \\
\hline (i) Beak to Beak contact & $\begin{array}{l}\text { birds fit one beak to the other and perform delicate movements by touching the } \\
\text { tongues or just touching the beaks. }\end{array}$ \\
\hline (ii) Allopreening or Mutual allopreening & $\begin{array}{l}\text { the bird cleans another individual's feathers, especially in regions that are } \\
\text { difficult to clean, such as the head, neck and cloaca region. The behavior can } \\
\text { be mutual between the partners. }\end{array}$ \\
\hline (iii) Food and/or object sharing & $\begin{array}{l}\text { the animal moves forward, downward, backward and upward with its head, } \\
\text { causing the food to move from the ingluvium to the beak (undigested food). } \\
\text { Then it moves from beak to beak and delivers the food to the other. When } \\
\text { observing the partner manipulating an object, the bird approaches gently and } \\
\text { with its beak tries to remove the object from the other, who can accept to share } \\
\text { it. }\end{array}$ \\
\hline (iv) Staying together & without sign of quarreling or annoyance. \\
\hline
\end{tabular}


In Table 1, complete descriptions of the determinant behaviors of peers among individuals can be seen. Such behavioral criteria, described by Favoretto (2016), were considered as indicative of the formation of pairs in the present study if observed between two individuals for at least 3 continuous weeks.

\section{Results}

The results of the analysis of extracted DNA were satisfactory, in qualitative and quantitative terms, enough to allow the amplification of the molecular markers of all individuals to be sexed. The analysis revealed a significant variation in the concentration of DNA samples obtained (DNA concentration - average $94.32 \mathrm{ng} / \mu \mathrm{L}$, lowest value $3.1 \mathrm{ng} / \mu \mathrm{L}$; largest value 246 $\mathrm{ng} / \mu \mathrm{L}$ ). The mean values of the sample indicators were 1.72 for organic contaminants (lower value 1.33 , higher value 1.84 ) and 1.17 for protein contaminants (lower value 0.6 , higher value 1.74 ).

To test the relative efficiency of the three pairs of primers, four samples were selected from the 23 samples extracted. It was found that, even though different amounts of DNA were used and the DNA purity indicators of all samples used had been below the ideal established limits, all samples had the molecular markers amplified by PCR.

The results illustrated in Figure 1 show the visualization of amplified molecular markers. The use of molecular weight allowed to estimate the approximate sizes of the molecular markers (Table 2).

Figure 1. Agarose gel (2\%) stained with ethidium bromide, with samples of blue-and-yellow macaw A. ararauna amplified with three pairs of primers.

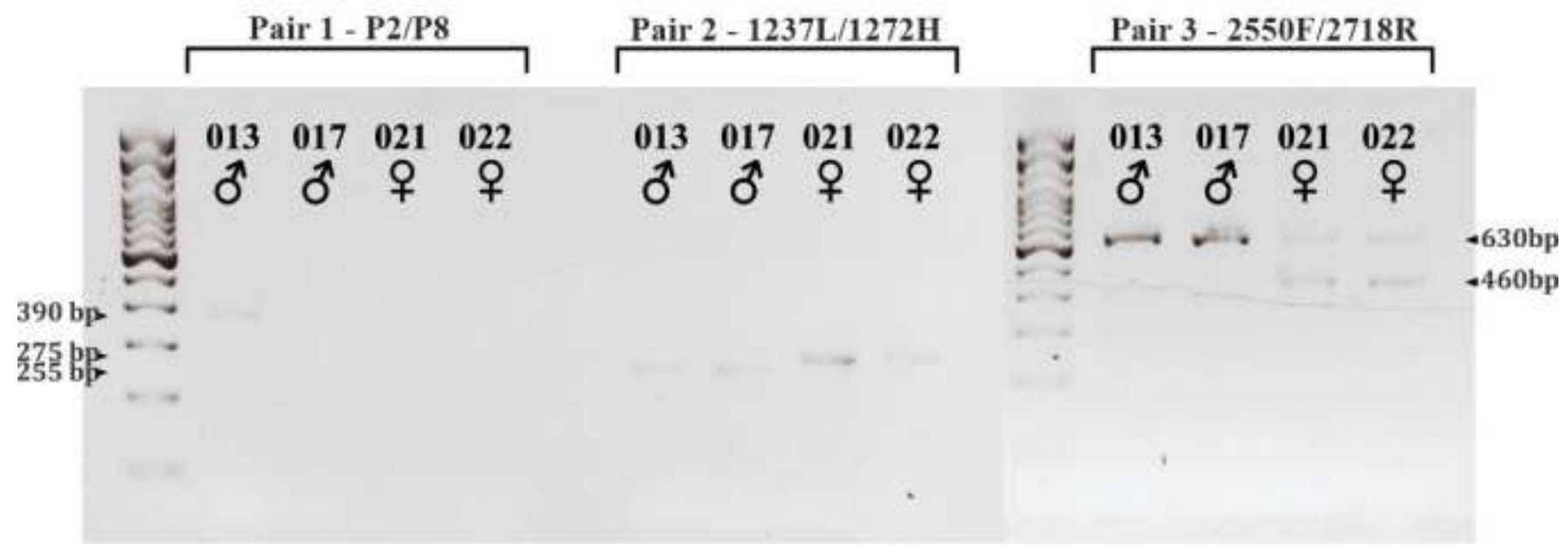

Source: Authors.

Figure 1 shows the following applied samples: allele-specific DNA fragments amplified from four blue-and-yellow macaw individuals (CETASUFBA 013, 017, 021 and 022). In the gel it is possible to visualize one fragment generated with Pair 1, two with Pair 2 and two with Pair 3. The estimated sizes of the molecular markers of the alleles were: Pair 1: Z - 390 bp; Pair 2: Z - 255 bp and W - 275 bp; Pair 3: Z - 630 bp and W - 460 bp. These sizes are indicated with arrows on the left and right of the gels. Fragments generated from primer Pairs 2 and 3 showed sufficient size differences to allow sexing. The individuals CETASUFBA 013 and 017 were genotyped as males and the individuals CETASUFBA 21 and 22 as females. The molecular weight marker used was the 100 bp DNA ladder (Invitrogen®); applied in the first well of the image of the first gel (left) and the third gel (right). 
Table 2. Estimated sizes of allele-specific molecular markers generated from three pairs of primers in the sexing of blue-andyellow macaw A. ararauna, in the present work.

\begin{tabular}{lccc}
\hline Allele-specific molecular marker & $\begin{array}{c}\text { Pair of primers 1 } \\
(\mathbf{P 2 / P 8})\end{array}$ & $\begin{array}{c}\text { Pair of primers 2 } \\
(\mathbf{1 2 3 7} / \mathbf{1 2 7 2 H})\end{array}$ & $\begin{array}{c}\text { Pair of primers 3 } \\
(\mathbf{2 5 5 0} / \mathbf{2 7 1 8 R})\end{array}$ \\
\hline Molecular marker Z (bp) & 390 & 255 & 630 \\
Molecular marker W (bp) & - & 275 & 460 \\
Size difference between amplified fragments (bp) & - & 20 & 170 \\
\hline
\end{tabular}

Source: Authors.

The estimated sizes shown in Table 1 were: (i) for the Pair of primers 1: band Z - $390 \mathrm{bp}$, the band W was not observed. (ii) For Pair of primers 2: band Z - 255 bp, band W - 275 bp. (iii) For the Pair of primers 3: band Z - 630 bp, band W - 460 bp. The size differences between the molecular markers generated by both Pair 2 (approximately 20 bp) and Pair 3 (approximately $170 \mathrm{bp}$ ) were sufficient to allow the separation of the molecular markers on agarose gel, and consequently for the sexing of the individuals. Pair 3 showed better sexing performance. This performance is due to the Pair of primers 3 having sizes of allelespecific bands with the largest difference in size between each other, thus being better separated in agarose gel.

Three annealing temperatures were used in the thermocycling program for the Pair of primers 3 , with the intention to verify which one would allow better visualization of the bands in agarose gel. At $55{ }^{\circ} \mathrm{C}$ (Figure 1), a smaller number of nonspecific bands were observed; but the allele-specific bands were visualized in a lower intensity, when compared with the allele-specific bands obtained with the temperature of $53{ }^{\circ} \mathrm{C}$. The temperature of $53{ }^{\circ} \mathrm{C}$ (Figure 2) amplified the allele-specific bands with higher intensity, facilitating their visualization; although nonspecific bands were also observed. At $51{ }^{\circ} \mathrm{C}$, nonspecific bands were generated; whereas allele-specific bands were visualized with less intensity, when compared with the bands obtained at a temperature of $53{ }^{\circ} \mathrm{C}$. It is understood here by specific bands those with estimated sizes of 630 bp for the $\mathrm{Z}$ marker and $460 \mathrm{bp}$ for the $\mathrm{W}$ allele. Thus, the present work establishes $53{ }^{\circ} \mathrm{C}$ as the best temperature to be used in the thermocycling program for amplification of the molecular markers $\mathrm{Z}$ and $\mathrm{W}$ of blue-and-yellow macaw with the Pair of primers 3.

Figure 2. Agarose gel (2\%) stained with ethidium bromide, with molecular markers of blue-and-yellow macaw A. ararauna amplified by Pair of primers 3 .

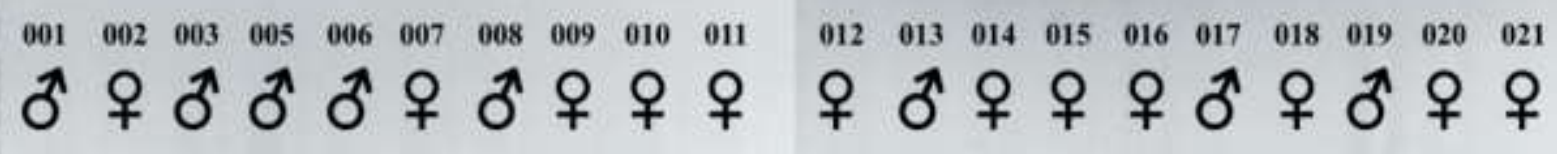

Source: Authors. 
Figure 2 shows the following applied samples: from 001 to 021 , equivalent to 20 individuals whose sex was determined using Pair of primers 3 (2550F / 2718R). Below the identification of each individual the gender is identified with the universal symbol for male or female. The estimated sizes of the molecular markers of the alleles were Z-630 bp and W-460 bp (indicated with arrows on the left of the images). 100bp DNA ladder marker (Invitrogen®) is applied (i) to the first well of the first gel image (left) and (ii) to the first well of the second gel (right).

The determination of the sex of the 23 individuals was performed using Pair of primers 3 (2550F / 2718R), with separation of the fragments by electrophoresis in $2 \%$ agarose gel. Figure 2 shows the genotyping of 20 of the 23 individuals. The molecular sexing of the 23 individuals showed a sample composition of 10 males and 13 females. This composition equals the approximate frequencies of 0.4 males and 0.6 females. Of the 23 individuals in the sample, 16 were forming pairs (approximately $70 \%$ ). Of the eight pairs observed, six were heterosexual pairs (approximately 75\%). Here are the heterosexual pairs: male $\mathrm{x}$ female (003 x 007; 006 x 012; 008 x 009; 010 x 023; 017 x 016; 019 x 020) CETASUFBA washers. Two homosexual pairs were observed, one consisting of two females (CETASUFBA $011 \mathrm{x}$ CETASUFBA 018) and the other by two males (CETASUFBA005 x CETASUFBA013). Follow the individuals who did not form pairs: 001, 002, 014, 015, 021, 022 and 024 CETASUFBA washers. All individuals were reintroduced into the wild with similar characteristics to the biomes where the species is found. The washers mentioned here can be used in the future to verify the maintenance of pairs or the formation of new pairs.

\section{Discussion}

\subsection{Adequacy of the DNA protocol used for the molecular sexing}

The DNA extraction protocol used is considered an alternative to the Sample Preparation Protocol on FTA (Manual GE Healthcare Life Sciences $\left.{ }^{\circledR}\right)$ cards for DNA extraction. The results were satisfactory, because although the analyzes showed significant variations in the concentration of the DNA samples, these variations were not sufficient to affect the amplification of the material and its subsequent visualization in agarose gel. Specifically, adequacy was (i) one hundred percent efficient considering amplifications with Pair of primers 3 (samples of twenty-three individuals were amplified), (ii) probable considering pair of primers 2 (amplification of samples of four individuals tested), and (iii) not suitable for use with primer pair 1 (amplification of one of the four DNA samples used).

The main modification of the DNA extraction protocol used in this work in relation to the protocol described for the use of FTA cards (Whatman ${ }^{\circledR}$ ), was the replacement of the FTA card for sterile filter paper. It does not contain substances that promote cell lysis. Vieira, Coelho and Oliveira (2009) performed sexing on 10 species of birds (including species of the family Psittacidae, but not including macaws) involving the use of three DNA extraction protocols: (i) Procedure used by Sambrook, Fritsch and Maniatis (1989), involving the use of phenol / chloroform and proteinase K enzyme; (ii) Simple and rapid alkaline extraction protocol, described by Rudbeck and Dissing (1998) for human DNA samples (blood and semen); and (iii) Modified alternative protocol from the Manual of preparation of samples using FTA cards. According to Vieira et al. (2009), the third protocol mentioned here was as efficient as the others were, but at a reduced cost. Regarding the quantity and quality parameters evaluated in the DNA extracted in the present study, it was not possible to compare with data in the literature because there are few articles mentioning it.

\subsection{Best pair of primers for molecular sexing}

The three pairs of primers were used to determine which would be most suitable for molecular sexing. Using Pair of primers 1 , it was possible to visualize only one band (estimated size $390 \mathrm{bp}$, equivalent to the $\mathrm{Z}$ allele). It appeared in only one of the samples, this being the individual CETAS UFBA 013 (genotyped as male). We believe that either (i) or there was no 
amplification of the molecular markers from the DNAs of the other three individuals tested for amplification with the primer pair 1, (ii) or the amplified fragments were not generated in sufficient quantity for all bands to be visualized on agarose gel. A possible explanation for the difference in the performance of primer pair 1 between the results of the articles mentioned in this text and those obtained in the present work is the DNA quality of the samples used. It is worth remembering that the works compared here were used of DNAs obtained through different DNA extraction protocols.

Amplified DNA with Primer Pair 1 (P2 / P8) Griffiths et al. (1998), studying owl Strix aluco, reports that it was not possible to visualize difference between the two allele-specific bands in 3\% agarose gel. Griffiths et al. (1998); Dubiec and Zagalska-Neubauer (2006) recommend that when molecular markers were amplified with Primer pair 1 (P2 / P8), acrylamide gel was used because this type of gel favors greater separation of allele-specific bands. Miyaki, Duarte, Caparroz, Nunes and Wajntal (1997) performing work with 3 orders and 43 species of birds (including blue-and-yellow macaw), reports how it is possible to visualize amplified allele-specific bands using $3 \%$ agarose gel. Dawson et al. (2001) worked with four species of birds of the family Alcidae: Aethia pygmaea, A. pusilla, A. cristatella and Cyclorrhynchus psittacula. In this work it was not possible to visualize, using $2 \%$ agarose gel, the size difference between the molecular markers amplified in each species. Jensen et al. (2003), carried out work with 10 orders and 47 bird species (including blue-and-yellow macaw); in blue-and-yellow macaw obtained DNA fragments of sufficiently different sizes for agarose gel sexing $2-3.3 \%$. Çakmak, Pekşen and Bilgin (2016) were successful in the amplification and separation of allele-specific bands in capillary electrophoresis of 77 bird species (including blue-and-yellow macaw) using 3\% agarose gel.

The Pair of primers 2 was used for molecular sexing in the articles in sequence: (i) Kahn et al. (1998) working with species of 9 orders of birds (not including the order Psittaciformes) and agarose gel 2\%, found differences of 210 up to 285 bp between the allele-specific fragments of the species studied. These authors report that the difference in size between the bands amplified by the Pair of primers 2 varies from species to species, such differences being due to the variations of the sizes of the introns in each of them. (ii) Jensen et al. (2003), working with 10 orders and 47 bird species (including blue-and-yellow macaw); in blue-and-yellow macaw obtained DNA fragments of sufficiently different sizes for sexing using $2-3.3 \%$ agarose gel electrophoresis. (iii) (Thanou, Giokas, Goutner, Liordos \& Fraguedakis-Tsolis, 2013) (not including individuals from the Psittacidae family) and using $4 \%$ agarose gel and possibly $16 \%$ acrylamide, found a difference between the bands amplified by the Pair of primers 2 varying between species in the range of $20-100 \mathrm{bp}$.

Here are cited some articles that worked with allele-specific molecular markers for molecular sexing generated by Pair of primers 3 (2550F / 2718R). Fridolfsson and Ellegren (1999) working with 11 orders of birds (including the order Psittaciformes, but not including blue-and-yellow macaw) and using 3\% agarose gel, observed differences between allelespecific bands of $150 \mathrm{bp}$ for Gallus gallus. Thanou et al. (2013) (Phalacrocoracidae) on $4 \%$ agarose gel and eventually acrylamide $16 \%$, observing a mean difference of $250 \mathrm{bp}$ between allele-specific fragments. Vucicevic et al. (2012) performed sexing with 58 species of birds (including blue-and-yellow macaw) using a 2\% agarose gel, observing a difference between 150 and 250 bp between the molecular markers of each species studied. Çakmak et al. (2016) studying 77 species of birds (including blue-andyellow macaw), using capillary electrophoresis, observed a mean difference between 265 bp allele-specific bands.

Molecular markers indicating the $\mathrm{Z}$ and $\mathrm{W}$ alleles generated by the same pair of primers with the greatest size difference between them are more efficient in distinguishing the sex genotypes after gel electrophoresis, which is especially relevant when using agarose gel. This gel, when compared to acrylamide gel, is considered less resolutive. However, the agarose gel shows significant advantages, such as easier and quicker to prepare, less costly and less toxic.

From the sexing studies in birds, the ones that were shown to be closer (by the studied species and techniques used) and that had more precise information to have their results compared with those of the present work are those of Jensen et al. (2003); Thanou et al. (2013) and Çakmak et al. (2016). The articles by Miyaki et al. (1997) and Vucicevic et al. (2012) do not specifically 
mention the sizes of the molecular markers obtained for the sexing of blue-and-yellow macaw. Table 3 shows the approximate sizes of the allele-specific bands obtained in the molecular sexing of blue-and-yellow macaw and biguas (family Phalacrocoracidae) using Primers 1, 2 and 3, considering data from Jensen et al. (2003); Thanou et al. (2013) and Çakmak et al. (2016).

Table 3. Estimated sizes of allele-specific molecular markers generated from three pairs of primers in the sexing of blue-andyellow macaw A. ararauna, in other works.

\begin{tabular}{lccc}
\hline Allele-specific molecular marker & $\begin{array}{c}\text { Pair of primers 1 } \\
(\mathbf{P 2 / P 8})\end{array}$ & $\begin{array}{c}\text { Pair of primers 2 } \\
(\mathbf{1 2 3 7 L / 1 2 7 2 H})\end{array}$ & $\begin{array}{c}\text { Pair of primers 3 } \\
(\mathbf{2 5 5 0 F / 2 7 1 8 R})\end{array}$ \\
\hline Molecular marker Z (bp) & $390^{*}$ & $290^{*}$ & $650^{* *}$ \\
& $369^{* * *}$ & $280^{* *}$ & $653^{* * *}$ \\
Molecular marker W (bp) & $410^{*}$ & $310^{*}$ & $400^{* *}$ \\
& - & $300^{* *}$ & - \\
Size difference between amplified fragments (bp) & 20 & 20 & 250 \\
& - & 20 & - \\
\hline
\end{tabular}

*Estimated sizes of bands obtained for blue-and-yellow macaw, by Jensen et al. (2003). **Banding sizes obtained for bivalve family Phalacrocoracidae, by Thanou et al. (2013). ***Size of the Z band obtained for blue-and-yellow macaw, by Çakmak et al. (2016). Source: Survey done by the authors.

Observing the data in Table 3 it can be said that as for Pair of primers 1, the $\mathrm{Z}$ allele generated on this research was estimated (390 bp) as having the same size of the $\mathrm{Z}$ allele for blue-and-yellow macaw estimated by Jensen et al. (2003), but of different size from the $\mathrm{Z}$ allele to blue-and-yellow macaw, estimated by Çakmak et al. (2016) (369 bp). As for Pair 2 primers, the $\mathrm{Z}$ allele generated in the present work was estimated ( $255 \mathrm{bp}$ ) as having different size from the $\mathrm{Z}$ allele to blue-and-yellow macaw estimated by Jensen et al. (2003) (290 bp) and Z allele for cormorants estimated by Thanou et al. (2013) (280 bp). The $\mathrm{W}$ allele generated by Pair of primers 2 was estimated in the present work $(275 \mathrm{bp})$ as having different size from the $\mathrm{Z}$ allele to blue-and-yellow macaw estimated by Jensen et al. (2003) (310 bp) and Z allele for cormorants estimated by (Thanou et al., 2013) (300 bp). As for Pair of primers 3, the $\mathrm{Z}$ allele generated in the present work was estimated (630 bp) as having different size from the Z-allele allele estimated by (Thanou et al., 2013) (650 bp) and Z allele for blue-and-yellow macaw, estimated by Çakmak et al. (2016) (653 bp). The $\mathrm{W}$ allele generated by the Pair of primers 3 was estimated in the present work (460 bp) as having different size from the Z-allele for bulrushes estimated by Thanou et al. (2013) (400 bp). The size of the Z allele was not estimated for blue-and-yellow macaw by Çakmak et al. (2016).

Differences in size between allele-specific fragments can be explained (i) by different accuracy of fragment size estimation methods (whether in plate electrophoresis or capillary electrophoresis, and in acrylamide or agarose gel) and / or (ii) by genomic differences between species or varieties of the same species that underwent molecular sexing. The present work prioritizes the use of agarose as it is less toxic, quicker to prepare and cheaper. Such advantages are significant for studies of wild animal populations. Regarding the amplified molecular markers being allele-specific, the images of the gels and the statements of some of the articles mentioned here lead us to believe that all were specific. These results, not completely in agreement with the estimated size of the amplified molecular markers, call attention to how research in this area allows variations in results. 


\subsection{Best Thermocycling Program for Molecular Sexing}

The molecular markers $\mathrm{Z}$ and $\mathrm{W}$ had already been amplified using the Pair of primers 3 (2550F / 2718R) by: (i) Vucicevic et al. (2012), (ii) Thanou et al. (2013) and (iii) Çakmak et al. (2016). Comparing with the three articles mentioned here, the article by Vucicevic et al. (2012) was the one that worked with more similar parameters of the present study: sexing of blue-and-yellow macaw and use of electrophoresis on agarose gel plaque. For this reason, we opted to optimize in the present work the conditions of amplification of the molecular markers of blue-and-yellow macaw using the Pair of primers 3 from the protocol of Vucicevic et al. (2012).

According to Vucicevic et al. (2012), there was amplification of only allele-specific bands at the temperature of $55^{\circ} \mathrm{C}$, described by the authors as Protocol 3 (P3). The present work showed that although using thermocycling at $55{ }^{\circ} \mathrm{C}$, there is a decrease in the amplification of nonspecific bands, at $53{ }^{\circ} \mathrm{C}$ we obtain specific bands more visible in gel. Non-specific bands are easily disregarded at sexing due to sizes not coinciding with the expected sizes of the molecular markers used for sexing. Thus, we recommend thermocycling for the molecular sexing of blue-and-yellow macaw using Pair of primers 3 with $\mathrm{Tm}$ at $53{ }^{\circ} \mathrm{C}$, instead of the other possible temperatures.

\subsection{Sex ratio of blue-and-yellow macaw in captivity}

The prevalence of the sexes found in the sample of blue-and-yellow macaw in the CETAS-VDC was 0.6 females and 0.4 males. We believe that this proportion is representative not only of the sample used, but also of the prevalence of the sexes in macaws (all blue-and-yellow macaw) of the institution that housed them. The 23 macaws studied in the present study were randomly selected from 34 blue-and-yellow macaw allotted in the CETAS, all located in the same enclosure. Caparroz, Guedes, Bianchi and Wajntal (2001) found sexual proportion for blue-and-yellow macaw wild (0.44 females and 0.56 males) similar to that of the present article. According to the authors, these differences are not statistically significant in relation to the ratio of $1: 1$.

\subsection{Occurrence of heterosexual and homosexual pairs in captive blue-and-yellow macaw}

The blue-and-yellow macaw has monogamous reproductive behavior, forming lifelong pairs that are only reformulated in the absence of one of the partners. According to Allgayer and Cziulik (2007), captive psittacines exhibit characteristic behaviors that may be indicative of paired formation. For pairs to be formed among psittacines in captivity, there must be compatibility between the two individuals involved so that, they can live in harmony. It is possible to detect through observation that animals prone to join in pairs demonstrate mutual interest, as described by their characteristic behaviors (Allgayer \& Cziulik, 2007).

Favoretto (2016) described behavioral patterns, including behaviors indicating the constitution of pairs for Lear's macaw Anodorhynchus leari in captivity. When comparing the indicative patterns of behavior to identify pairs proposed by Favoretto (2016) with those by Allgayer and Cziulik (2007), Favoretto (2016) proposes more types of behavior patterns. These include: (i) Beak to beak contact, (ii) Allopreening or mutual allopreening, (iii) Food and/or object sharing, and (iv) Staying together without sign of quarreling or annoyance. These were the ones adopted by the present work for the identification of pairs.

Bagemihl (1999) documented the composition of pairs involving individuals of the same sex in about 450 species of mammals and birds. In a review by MacFarlane, Blomberg and Vasey (2010), 83 species of wild birds showed occurrence of homosexual pairs. Dagg (1984) describes that the composition of homosexual pairs in mammals occurs most often in captivity. Bagemihl in 1999, describes pairs made up of individuals of the same sex are found in free life and captivity, but more frequently in animals kept in captivity. Allgayer and Cziulik (2007) also describe how common, in collective enclosures, the formation of pairs between birds of the same sex. Bagemihl (1999) reports that in birds there are species in which there are individuals entering 
simultaneously and / or in sequence in heterosexual and homosexual pairs, which is observed especially in monogamous species. Mills (1994), reports individuals from the family Laridae (family of gulls and scissor beaks), consisting of monogamous species, composing female-female pairs. Hardy (1963) and Buchanan (1966) performed work with Eupsittula canicularis parakeets, describing the formation of female-female pairs kept in captivity (Hardy, 1963) and male-male pairs in wild population (Buchanan, 1966).

In the present study, the combination of sexing and observation of the individuals revealed that $70 \%$ of the sample of individuals in the CETAS-VDC enclosure were pairs, and $75 \%$ of the pairs were heterosexual pairs. Of the $25 \%$ of homosexual pairs observed, one was composed by males and the other by females. The above-mentioned sex ratio, not far from 1:1, suggests that heterosexual pairs were not formed due to lack of individuals of the opposite sex. The following are reports on the frequency of homosexual pairs in groups of animals or species in particular. Bagemihl (1999) described the frequency of $20 \%$ of homosexual pairs among 450 individuals (including birds and mammals), considering wild animals and kept in captivity. Kotrschal, Hemetsberger and Weiss (2006), found that in the monogamous goose-goose Anser anser $12 \%$ to $20 \%$ of pairs in the wild population were individuals of the same sex. (Young, Zaun \& VanderWerf, 2008), described in a wild albatross population Phoebastria immutabilis, a frequency of $31 \%$ of homosexual pairs, with formation of only female-female pairs. When comparing the frequency of homosexual pairs found in the sample of the present study $(25 \%)$ with those published in the literature, a similar frequency is observed.

We emphasize that the present study has its importance also linked to the management process necessary for the reintroduction of the species to nature. The frequency of heterosexual pairs is important to ensure the reproductive success of species both in captivity and in reintroduction programs. The reproductive success of the species is directly related to the frequency of homosexual pairs, since the female-female pairs imply the non-fertilization of the eggs and the male-male pairs involve the non-egg laying. In other words, homosexual pairs can bring low fertility rates in the communities that have them (Breuner, 2011). Therefore, the frequency of heterosexual and homosexual pairs has a direct impact on the reintroduction programs, including programs promoted by CETAS; which aim to ensure the reproductive success of individuals in the environment in which they are reintroduced. The research conducted by Sanz and Rodriguez-Ferraro (2006), for example, reaffirm the necessity to prioritize the reproductive success of the species, referring to Amazona barbadensis both in captivity and in the environment in which they will be reintroduced.

No information was found in the scientific literature on the composition (nor the frequency) of same sex pairs in macaws and blue-and-yellow macaw (wild or in captive). Considering the above, even considering sample of individuals in captivity and relatively limited sample size $(n=23)$, we believe that this work brings significant contributions to the understanding of the biology and behavior of macaws, especially of the species A. ararauna.

\section{Conclusion}

Therefore, the present study demonstrated that in relation to the selection of parameters for molecular sexing of blueand-yellow macaw (i) the low complexity DNA extraction protocol used was adequate; (ii) Pairs of primers 2 and 3 were effective for sexing; (iii) and the Pair of primer 3 was the most efficient. The study also showed that in the sample of wild blue-and-yellow macaw studied in CETAS-VDC, (iv) the sample composition of males and females was similar ( 0.4 males $\mathrm{n}=10$ and 0.6 females $\mathrm{n}=13)$, (v) $70 \%(\mathrm{n}=16)$ of the individuals were distributed in pairs, (vi) being $75 \%(\mathrm{n}=12)$ of the heterosexual pairs, and (vii) having male-male and female-female pairs.

Our data reinforce the importance to use molecular biology along with conservation monitoring. Through assertive and accessible technics, this work elucidated the formation of pairs among blue-and-yellow macaw improving the reintroduction strategy of these animals. We hope that these results encourage and provide new insights about reintroduction of species that do 
not present sexual dimorphism. These results can also help the development of conservation measures of A. ararauna and contribute to future research about general bird reintroduction in nature by monitoring pairs formation.

\section{References}

Ágh, N., Kovács, S. Z., Nemesházi, E., \& Szabó, K. (2018). Univerzális, ivarhatározáshoz használt CHD1 markerek alkalmazhatósága különböző madárrendekben. Magyar állatorvosok lapja, 140(1), 47-59.

Allgayer, M. C., \& Cziulik, M. (2007). Reprodução de psitacídeos em cativeiro. Revista Brasileira de Reprodução Animal, 31(3), 344-350.

Altmann, J. (1974). Observational study of behavior: sampling methods. Behaviour, 49, 227-267.

Bagemihl, B. (1999). Biological exuberance: Animal homosexuality and natural diversity. St. Martin's Press.

Breuner, C. W. (2011). Stress and reproduction in birds. In D. O. Norris, \& K. H. Lopez (Eds.). Hormones and Reproduction of Vertebrates (Vol. 4, Chap. 5 , pp. 129-151). Cambridge: Academic Press.

Buchanan, O. M. (1966). Homosexual Behavior in Wild Orange-Fronted Parakeets. The Condor, 68(4), 399-400.

Çakmak, E., Pekșen, C. A., \& Bilgin, C. C. (2016). Comparison of three different primer sets for sexing birds. Journal of Veterinary Diagnostic Investigation, 29(1), 59-63.

Caparroz, R., Guedes, N. M. R., Bianchi, C. A., \& Wajntal, A. (2001). Analysis of the genetic variability and breeding behaviour of wild populations of two Macaw species (Psittaciformes, Aves) by DNA fingerprinting. Ararajuba, 9(1), 43-49.

Dagg, A. I. (1984). Homosexual behaviour and female-male mounting in mammals—a first survey. Mammal Review, 14(4), 155-185.

Dalfovo, M. S., Lana, R. A., \& Silveira, A. (2008). Métodos quantitativos e qualitativos: um resgate teórico. Revista Interdisciplinar Científica Aplicada, 2(4), 01-13.

Dawson, D. A., Darby, S., Hunter, F. M., Krupa, A. P., Jones, I. L., \& Burke, T. (2001). A critique of avian CHD-based molecular sexing protocols illustrated by a Z-chromosome polymorphism detected in auklets. Molecular Ecology Notes, 1(3), 201-204

Dubiec, A., \& Zagalska-Neubauer, M. (2006). Molecular techniques for sex identification in birds. Biological Lett, 43(1), 3-12.

Favoretto, G. R. (2016). Comportamento de arara-azul-de-lear (Anodorhynchus leari, Bonaparte, 1856) em cativeiro e a influência da técnica flocking na interação de pares. Dissertação de mestrado, Fundação Parque Zoológico de São Paulo, Universidade Federal de São Carlos, Sorocaba, SP, Brasil.

Franco-Gutiérrez, L. J., Álvarez-Cardona, J., \& Soto-Calderón, I. D. (2017). Sex identification of neotropical macaws (Ara spp.) from invasive and non-invasive samples. Ornitología Colombiana, (16), eNB03, 01-07.

Fridolfsson, A-K., \& Ellegren, H. (1999). A simple and universal method for molecular sexing of non-ratite birds. Journal of avian biology, 30(1), 116-121.

Gill, F., Donsker, D., \& Rasmussen, R. (Eds.). (2020). IOC World Bird List.v. 10.1. http://www.worldbirdnames.org/DOI-10/master_ioc_list_v10.1.xlsx

Griffiths, R., Double, M. C., Orr, K., \& Dawson, R. J. G. (1998). A DNA test to sex most birds. Molecular ecology, 7(8), 1071-1075.

Hardy, J. W. (1963). Epigamic and reproductive behavior of the orange-fronted parakeet. The Condor, 65(3), 169-199.

IBGE - Instituto Brasileiro de Geografia e Estatística. (2001). Fauna ameaçada de extinção. Centro de Documentação e Disseminação de Informações do IBGE.

BirdLife International. (2018). The IUCN Red List of Threatened Species: Ara ararauna. https://dx.doi.org/10.2305/IUCN.UK.2018-

2.RLTS.T22685539A131917270.en

Jankowiak, Ł., Tryjanowski, P., Hetmański, T., \& Skórka, P. (2018). Experimentally evoked same-sex sexual behaviour in pigeons: better to be in a femalefemale pair than alone. Scientific Reports, 8(1654), 1-7.

Jensen, T., Pernasetti, F. M., \& Durrant, B. (2003). Conditions for rapid sex determination in 47 avian species by PCR of genomic DNA from blood, shellmembrane blood vessels, and feathers. Zoo Biology, 22(6), 561-571.

Joseph, L., Toon, A., Schirtzinger, E. E., Wright, T. F., \& Schodde, R. (2012). A revised nomenclature and classification for family-group taxa of parrots (Psittaciformes). Zootaxa, 3205, 26-40.

Kahn, N. W., St. John, J., \& Quinn, T. W. (1998). Chromosome-specific intron size differences in the avian CHD gene provide an efficient method for sex identification in birds. The Auk, 115(4), 1074-1078.

Kotrschal, K., Hemetsberger, J., \& Weiss, B. M. (2006). Making the best of a bad situation: homosociality in male greylag geese. In V. Sommer, \& P. L. Vasey (Eds.) Homosexual behaviour in animals: an evolutionary perspective (Chap. 2, pp. 45-76). New York: Cambridge University Press.

MacFarlane, G. R., Blomberg, S. P., \& Vasey, P. L. (2010). Homosexual behaviour in birds: frequency of expression is related to parental care disparity between the sexes. Animal Behaviour, 80(3), 375-390.

Mills, J. A. (1994). Extra-pair copulations in the red-billed gull: females with high-quality, attentive males resist. Behaviour, 128(1-2), 41-64. 
Miyaki, C. Y., Duarte, J. M. B., Caparroz, R., Nunes, A. L. V., \& Wajntal, A. (1997). Sex identification of south american parrots (Psittacidae, Aves) using the human minisatellite probe 33.15. The Auk, 114(3), 516-520.

Ong, A. H. K., \& Vellayan, S. (2008). An evaluation of CHD-Specific primer sets for sex typing of birds from feathers. Zoo Biology, 27(1), 62-69.

Pereira, A. S., Shitsuka, D. M., Parreira, F. J., \& Shitsuka R. (2018). Metodologia da pesquisa científica. Núcleo de Tecnologia Educacional da Universidade Federal de Santa Maria. https://repositorio.ufsm.br/handle/1/15824

Breuner, C. W. (2011). Stress and reproduction in birds. In D. O. Norris, \& K. H. Lopez (Eds.). Hormones and Reproduction of Vertebrates (Vol. 4, Chap. 5, pp. 129-151). Cambridge: Academic Press.

Piacentini, V. Q., Aleixo, A., Agne, C. E., Maurício, G. N., Pacheco, J. F., Bravo, G. A., Brito, G. R. R., Naka, L. N., Olmos, F., Posso, S., Silveira, L. F., Betini, G.S., Carrano, E., Franz, I., Lees, A. C., Lima, L. M., Pioli, D., Schunck, F., Amaral, F. R., Bencke, G. A., Cohn-Haft, M., Figueiredo, L. F. A., Straube, F. C., \& Cesari, E. (2015). Annotated checklist of the birds of Brazil by the Brazilian Ornithological Records Committee. Revista Brasileira de Ornitologia, 23(2), 91298.

Rodríguez-Mahecha, J. V. R., Suárez, F. R., Arzuza, D. E., \& Hernández, A. G. (2005). Loros, Pericos \& Guacamayas Neotropicales. Bogotá: Conservación Internacional.

Rudbeck, L., \& Dissing, J. (1998). Rapid, simple alkaline extraction of human genomic DNA from whole blood, buccal epithelial cells, semen and forensic stains for PCR. BioTechniques, 25(4), 588-592.

Sambrook, J., Fritsch, E. F., \& Maniatis, T. (1989). Molecular cloning: a laboratory manual (Vol. 3, 2a ed.). Cold Spring Harbor Laboratory Press.

Sanz, V., \& Rodriguez-Ferraro, A. (2006). Reproductive parameters and productivity of the yellow-shouldered parrot on Margarita Island, Venezuela: a longterm study. The Condor, 108(1), 178-192.

Sick, H. (1997). Ornitologia brasileira. Nova Fronteira.

Smith, L. M., \& Burgoyne, L. A. (2004). Collecting, archiving and processing DNA from wildlife samples using FTA® databasing paper. BMC ecology, 4, 111 .

Souza, G. M., \& Soares-Filho, A. O. (2005). O comércio ilegal de aves silvestres na região do Paraguaçu e Sudoeste da Bahia. Enciclopédia Biosfera, 1(1), 111 .

Sulandari, S., \& Zein, M. S. A. (2012). Application of two molecular sexing methods for indonesian bird species: Implication for captive breeding programs in indonesia. HAYATI Journal of Biosciences, 19(4), 183-190.

Thanou, E., Giokas, S., Goutner, V., Liordos, V., \& Fraguedakis-Tsolis, S. (2013). Efficiency and accuracy of PCR-based sex determination methods in the European Phalacrocoracidae. Annales Zoologici Fennici, 50(1-2), 52-63.

Vieira, J. N., Coelho, E. G. A., \& Oliveira, D. A. A. (2009). Sexagem molecular em aves silvestres. Revista Brasileira de Reprodução Animal, 33(2), 66-70.

Vucicevic, M., Stevanov-Pavlovic, M., Stevanovic, J., Bosnjak, J., Gajic, B., Aleksic, N., \& Stanimirovic, Z. (2012). Sex determination in 58 bird species and evaluation of CHD gene as a universal molecular marker in bird sexing. Zoo biology, 32(3), 269-276.

Young, L. C., Zaun, B. J., \& VanderWerf, E. A. (2008). Successful same-sex pairing in Laysan albatross. Biology Letters, 4(4), 323-325. 